\title{
South African Crime and Detective Fiction in English: A Bibliography and Publishing History
}

\author{
Elizabeth le Roux
}

\begin{abstract}
Against the general assumption that crime and detective fiction has only recently emerged as a genre in South African publishing, this essay will consider the publishing history of this genre in South Africa. The question that is considered is whether trade or general-interest publishers targeting a mass audience in South Africa have produced 'whodunnits' in addition to their output of cookbooks and romance fiction? The evidence of writers like June Drummond, James McClure and Wessel Ebersohn, at the very least, suggests that they have, but there is also an older history. This article aims to develop a bibliography and publishing profile of this genre. This will enable us to build a contextualised historical perspective and deepen our understanding of a very popular genre.
\end{abstract}

Keywords: bibliography; dissemination; marketing; paratext; publishing history; trade publishing

\section{Introduction}

It is generally assumed that crime and detective fiction has only recently emerged as a genre in South African publishing. Mike Nicol, for instance, comments on his Crime Beat blog that, "Despite the vibrancy of thriller and crime fiction elsewhere, not much has happened in SA crime fiction over the last five decades" (n.d.). Although he locates June Drummond's The Black Unicorn (1959) as the first crime novel in English, he, like many other academics and commentators, appears to downplay what came before - and to some extent afterwards, until the 1990s. Overviews of South African literature tend to either ignore detective and crime fiction altogether, or mention a few key proponents, such as James McClure, June Drummond, and Wessel Ebersohn (see, e.g. Killam \& Kerfoot, 2008: 249; Hubin, 2008; Herbert, 1999). There has also been a recent proliferation of clearly untrue yet widely accepted statements such as that Angela Makholwa - according to her Wikipedia entry - is "the first black writer to write crime fiction in South Africa" (2012). Warnes is more accurate in saying that "the detective returns to South African literature with a vengeance" (2012: 986), than those seeing the "explosion" of crime writing from the 1990s as an entirely new phenomenon.

This article will attempt to provide a more nuanced basis for such statements, by considering the publishing history of this genre in South Africa. This approach to literary history considers the role of publishers, not as intermediaries, but as central role-players in the process of producing and disseminating books. The focus on publishing rather than writing is a deliberate one, as there has been little consideration in the literature of the role of the publisher in marketing and disseminating mass-market genres of fiction. The incorporation of social, market and other forces also enables an alternative and more contextualised perspective on the production of South African fiction. Using Susan Friedland's bibliography, "South African detective stories in English and Afrikaans from 1951-1971" (1972), as a starting point, this article will attempt to develop a more complete publishing profile of this genre, focusing on works written in 
English: the publishers involved and their strategies and motivations, the authors, the circulation of crime and detective fiction, and the paratext of books (cf. Genette, 1997). The article will also emphasise the commercial decision-making process associated with publishing.

\section{A bibliographical basis: issues of classification}

A publishing profile is based, first of all, on a bibliography of works published in a specific period. Revealing sporadic but on-going interest in the publication of detective and crime fiction, Friedland was able in 1972 to list 70 titles in English and 451 in Afrikaans. Friedland built the Afrikaans section of the bibliography on Anita Miller's "Afrikaanse speurverhale uitgegee tot die einde van 1950" (1967), but the English-language section was the first such bibliography compiled in South Africa. Seventy titles in twenty years seems a healthy output rate, but, on closer inspection, the list of English titles is in reality much fewer. Friedland included various foreign authors who set parts of their works in South Africa, as well as some South African-born authors who later settled abroad and set their works almost entirely in those overseas settings. The use of further bibliographical resources enables us to build a more detailed bibliography of crime fiction in English in South Africa. These include Schleh's (1991) bibliography of African mysteries (which repeats much of Friedland's work), Spehner's (2012) online bibliography of crime fiction from Africa, the African Crime Fiction Project (n.d.), and the CrimeBeat "Who's Who" of South African detective fiction (n.d.). The resulting collection of bibliographical data is almost certainly incomplete, but provides a good starting point for discussion.

The issue of definition is a significant one when developing a bibliography, as definitional criteria function as markers for inclusion or exclusion. To begin with, the precise definition of publishing in the English language in South Africa is problematic, as in so many former colonies, because of the dependence on the imperial centre (see Ensor, 2008, for a consideration of the "clot of definitional issues" in relation to Australia). A South African author, for instance, is a tricky concept to define, raising questions of cultural identity and ownership. Writers may have been born in the UK, but considered themselves largely South African, while others may have been born in South Africa, but saw the UK as 'home'. The early writers may more accurately be termed 'Anglo-African' than either 'South African' or 'British'. It has been argued that this is true, to an ever greater extent, for crime fiction, as it is published in such a wide variety of languages, covers so many kinds of settings, and features such a mix of people: "[C]rime fiction increasingly transcends, if not invalidates, national boundaries" (Matzke \& Mühleisen, 2006: 8).

Place of publication is equally tricky: there was very little book publishing at all in South Africa until the mid-twentieth century, especially in English. It was widely assumed that the reading needs of South Africans would be catered for by books imported from the United Kingdom. Until as late as World War II, South Africa was seen simply as a lucrative overseas market for UK publishers. For a number of reasons, publishing in the former British colonies began to grow after the war, emerging from what the publisher Allen Lane called an "absorbent phase" into a "creative phase" (qtd in Tian, 2008: 16). The pattern in South Africa was complicated by the multilingual situation, and in particular the strong promotion of Afrikaans alongside Afrikaner nationalism: thus, on the one hand, "[t]he post-colonial period from 1910 to 1960 saw the development of a very strong publishing movement in support of the strong Afrikaner language nationalism which grew after the Anglo-Boer War", while, on the other hand, "[m]ost books in English were imported from Britain, and most South African writers published in British publishing firms" (Hooper, 1997: 72). As a result, local authors writing in English would have been more inclined to turn to foreign-based publishers. The reasons are related to the small local market, but also to lingering colonial traces: "Because the consumer market for fiction is small, mass-market fiction has always originated outside the South African publishing 
industry" (Evans \& Seeber, 2000: 226). One of the implications is that literary tastes among the South African reading public have largely been pre-determined by the publishing industry and readership in the UK.

It is self-evidently true that more crime and detective fiction is now being published in South Africa than at any time in the past; this is not only due to the rise in popularity of this genre among local readers, authors and publishers, but also to the overall rise in output rates in the publication of local titles. However, this is not to say that very little was published before the 1990s, and a further issue of definition may be partly responsible for this assumption. This relates to the way in which fiction is classified and packaged. While crime fiction is now seen as a genre in its own right, it overlaps with various other genres, including adventures, thrillers, mysteries, spy stories, and so on. Wilbur Smith's novels are a case in point, seldom classified as crime fiction because they are seen, to a greater extent, as adventures and dramatic family sagas.

The usual classification used by a publisher or bookseller is the broad 'Mystery/Detective' or 'Crime Fiction' category, while 'Suspense/Thrillers' is a separate but related category. In the UK and South Africa, the book data aggregator Nielsen Bookscan uses a much broader category when tallying sales data, namely 'Crime, Thriller \& Adventure' (see Betts, 2012: 38). This is a deliberate strategy, as Matzke and Mühleisen point out: "[T]he very diversity of the genre is often obscured by marketing strategies of publishing houses where a clear identification of the genre is a vital selling point" (2006: 2). Thus, the contentions in literary criticism around the fine differences between detective fiction, crime, mystery, thriller, suspense, and so on (and even finer distinctions among different detective genres), are obscured by publishers attempting to reach as wide an audience as possible. That factor - the audience - is what drives the publication of mass-market fiction, and thus, if "in the mind of the reading public the detective story often merges with spy fiction and science fiction, because all are mysteries" (Dove, 1997: 1), then publishers will take pains to categorise their works as broadly as possible. Indeed, "[i]n any genre in which survival is directly dependent upon sales, the expectations of the reader determine the pre-intentions of the genre" (Dove, 1997: 73). In publishing terms, this means that the audience's expectations for a specific genre are translated into a set of conventions around book titles, cover designs, the writing of back-page blurbs, marketing and advertising strategies - all in the name of increasing sales to a mass-market readership. Crime fiction is thus, pre-eminently, commercial, conventional and competitive: "a genre ... saleable to publishers ever hungry for more series" (Morse, 2005: 82).

\section{The forerunners}

The Oxford Companion to Crime and Mystery Writing (Herbert, 1999) identifies the "first crime work written by a writer born or resident in an African country and set in modern Africa" as an anonymous spy and mystery novel published by John Macqueen in London in 1901: Kruger's Secret Service by "One Who Was In It". Although not a detective story as such, the work deals with an English businessman who joins the Transvaal Secret Service as a double agent on behalf of the British, and details his informal police work and the attempted murder of "Mr Cecil Rhodes". The author was later identified as Douglas Blackburn (1857-1929), a journalist who lived in South Africa between 1892 and 1908. Under his own name, Blackburn published several novels, but none of these falls into the crime genre. Kruger's Secret Service is readily available as an e-book, and has also been re-issued by Bastian Books (Canada) as recently as 2008 - now distinctly classified as "crime fiction" and indeed as a classic of this genre.

The novel is overtly aimed at a British readership, with the narrator actively interpellating this audience through comments like, "it may be of interest to the British public ..." (p. 19). It was widely read internationally, as evidenced by a review in the Australian Bathurst Free Press and Mining Journal of 10 January 1901. This appeal to an international readership highlights 
two seemingly contradictory strands, which will be immediately familiar to regular readers of detective fiction: emphasising the universality of human behaviour and experience, within an exotic or unusual setting. This mingling of the familiar and the exotic is one of the selling points of detective and crime fiction, and one which publishers often take pains to exploit.

But a little bibliographical detective work leads us to believe that this is not, in fact, the origin of crime fiction in South Africa. If we go back a decade further, then such origins can be traced to the first wave of Anglo-African fiction writers and the genre of adventure writing or the imperial romance. Authors writing at the same time as H. Rider Haggard, in the 1890s, include Ernest Glanville and Bertram Mitford, who incorporated aspects of what is now recognised as the crime genre into their writing. These authors have received little scholarly attention, and their works are now almost completely unknown - although several titles may undergo a revival of interest as they become available in digital editions.

Glanville was a South African journalist, who lived and worked in both South Africa and England. His work would now largely be classified as romance, drama or adventure, but the resolution of a crime or mystery is central to most (see Monsman, 2011). Max Thornton (London: Chatto $\&$ Windus, 1901), one of Glanville's novels of the Boer War, comes up repeatedly in bibliographies of crime fiction (e.g. Hubin, 2008), but is not the best representative of the genre among his seventeen novels. Rather, The Lost Heiress: A Tale of Love, Battle and Adventure (London: Chatto \& Windus, 1891) presents a mixture of sub-plots revolving around "love, jealousy, and fratricidal murder" (Monsman, 2011: 325). And A Fair Colonist (London: Chatto \& Windus, 1894) features Ada Tamplin, who is kidnapped and must be tracked down; the crime here is a kidnapping rather than a murder, but the plot nonetheless involves the solving of a mystery.

Mitford is also a good contender as the first crime writer in South Africa. Although born in England, he lived most of his life in South Africa and set many of his titles in this country. Lieven (1998) has discussed how Mitford's work strains the boundaries of the traditional imperial adventure genre, as he incorporates aspects of what we now recognise as more distinct genres into his work, including crime fiction. Examples include his most successful work, The Sign of the Spider (London: Dodd, Mead \& Co, 1896) and Renshaw Fanning's Quest (London: Chatto \& Windus, 1894). The Weird of Deadly Hollow: A Tale of the Cape Colony (London: F.V. White \& Co., 1899) is a ghost story and psychological thriller, set on the farm of 'Moordenaar's Hoek', and includes two murders and attempted murders, as well as a court case. The latter title may lay claim to being the first true South African crime fiction.

These titles were published by highly reputable London publishing houses - local publishers of English texts only really started to be established in the 1890s, with Thomas Maskew Miller in 1893 and the Central News Agency in 1896 - and were widely available and read in the colonies (including in South Africa), although their reputation does not appear to have lasted. Ford has described the contemporary reception of Mitford's work, noting that "colonial hostility and capital violence punctuate the pages of his tales, as do scenes of rapacious slaughter" (2009: 7-8). Both Mitford and Glanville were also often compared to Haggard, although critics such as Monsman (2011) are now evaluating their work in a new light. Malvern Van Wyk Smith, for instance, has dismissed Mitford's work as "a highly saleable blend of Haggard's exotically inventive romance and the Victorian public school adventure" (1990: 24). The point that they were "highly saleable" is significant, especially from the publisher's point of view, and may explain why such prestigious publishers were willing to dabble in a range of genres.

\section{Colonial novels}

After these forerunners, a second grouping of crime writers can be identified around the 1920s and 1930s. This group will be referred to as "colonial", as they were largely English-born writers who 
settled in South Africa and situated their fiction here, although their approaches may have differed considerably. For instance, Gordon Gardiner, a Scottish soldier and journalist in South Africa, used this country as a setting for several of his novels, including The Reconnaissance (New York: Macmillan, 1914) and The Pattern of Chance (London: Sampson Low \& Marston, 1929). His novels were published by a variety of different publishers, but all feature elements of crime, and they were well received and widely reviewed. Evidence of reviews, for instance, can be found in newspapers as far afield as New Zealand and Australia. The reviews also clearly show the work's reception as detective fiction (see e.g. The Bookman of September 1928).

Similarly, William Westrup, an Englishman who worked for a mining company in South Africa, set Shadows in the Water (London: John Lang, 1929) here. The catalyst for the plot is a murder on a mine in South Africa. His other novels, produced between 1911 and 1937, also deal with mining as background or plot device. In contrast, L Patrick Greene, an English author who lived in Rhodesia and later emigrated to the USA, spent comparatively little time in South Africa, but chose to locate all of his novels in South Africa and Rhodesia. Although he published many short stories in adventure magazines from about 1918, his first book was The Major-Diamond Buyer (New York: Doubleday, Page \& Co, 1924). The publisher appears to have been responding to the widespread popularity of the short stories, and the character of the Major in particular, by requesting Greene to publish a collection as a book. Once this was successful, various collections and novels followed. These were published in attractive, hardcover editions, and are now considered collectors' items.

A further interesting example of a colonial author is Kathleen Lindsay, who was born in the UK, and lived in Australia and then South Africa from the 1940s. She died in Somerset West in 1973. What makes her of particular significance is that Lindsay once held the Guinness world record for the highest number of novels written by a single person, at 904. While most prolific in the romance genre, she also published crime fiction under at least two pseudonyms, Hugh Desmond and Nigel Mackenzie. The Desmond novels are largely located in the UK, with the character Alan Fraser of Scotland Yard - the first of these, The Slasher, appeared in 1939, just before Lindsay moved to South Africa. For such an abundant author, surprisingly little is known about Lindsay. While she published with a variety of popular publishers, her titles appear to have been co-published with a small Pietermaritzburg company called Albatross Publishing Company - at least, this is the name listed on the legal deposit copies of almost all of Lindsay's works - but little is known of this publisher.

The transnational publishing context led publishers to position such books primarily for an international audience - with the local audience being of secondary importance because of the size of the market. As a result, such works were largely packaged and marketed to highlight their 'exotic' locale, as mentioned earlier, and as can be seen in the paratextual elements of cover design and jacket copy. Gardiner played up his audience's simultaneous familiarity with and distance from the South African setting, playfully stating on the blurb that his was "possibly the only book regarding South Africa in existence where the word kopje never occurs". In similar vein, one of Agatha Christie's novels of the same period, The Man in the Brown Suit, sees the Southern African setting "shamelessly cast as an adventurous location for a bored and frustrated heroine" (Green, 1997: 193). Huggan notes how "[e]xoticist myths and stereotypes, apparently dismantled by the writers, reappear with a vengeance in the commercial packaging of their books ... Though publishers' agendas differ widely, they all know exoticism sells. African or Indian writing offers a window onto a different, exciting world" (1994: 26). Hofmeyr refers to this strategy, disparagingly, as "the inevitable ballast of a sensational plot with romance elements staged against a shallow background of local colour" (1978: 12). Yet this is still an important marketing technique for publishers, as evidenced by the popularity of waves of foreign writers, such as Scandinavian crime fiction, Latin American crime fiction, and so on. 


\section{Local publishing}

The first local publishing - as opposed to local writing or setting - of crime fiction can be traced to the late 1920s and 1930s, although it only really took root after the war. Nasionale Pers started a series of Afrikaans detective stories - Hendrik Brand's Adriaan Hugo series, of which the first title appeared in 1929 - and the Central News Agency (CNA) began issuing a paperback series under the Dassie Books imprint. The Dassie imprint lent itself to a mass-market genre like crime fiction, with its small, inexpensive formats, simple two-colour covers, and wide range of authors and themes. Examples of crime titles include Pot Holes: An Adventure of the Diamond Fields by Elizabeth Charlotte Webster (1927); Motives for Murder by Glynn Croudace (1950); Highveld, Lowveld and Jungle by Donald Swanson (1956); and Gold Without Glitter by Bob O'Keefe (1957). Several authors used Dassie as a step up to international publishers. For instance, Croudace moved to UK publishers as he became more prominent in the late 1950s and 1960s. These included Robert Hale, a publisher that became widely known for crime fiction set in 'exotic' colonial locales, including New Zealand, Australia and South Africa.

In the 1940s, more local publishers began to emerge, both generally and in terms of this genre. At least two factors may account for the local "book boom" after 1945: these were the "technical progress in printing and binding in South Africa during World War II and the virtual stoppage on book imports during the U-boat campaign" (Rosenthal, 1970: 281). But the "book boom", at least initially, did not produce many general or trade titles. Ad Donker, himself an important publisher from the 1960s on, dismissed local trade publishing as "consist[ing] mainly of Africana reprints and several books on gardening and local plants" (1983: 29). One of the first local trade publishers to begin producing mass-market titles in English was Howard Timmins. Timmins published the travel writer Lawrence Green very successfully; the latter sold more than 500000 copies in South Africa in the post-war period, a feat that is seldom equalled even today. Aptly, then, Timmins published one of the first local detective novels, Alexander Campbell's Fell Purpose, in 1945. This novel features Colonel Jurie Malan, "the Cape Sherlock" whose "speciality is murder" (p. 10). The plot twists and denouement are reminiscent of the work of Agatha Christie.

Campbell's sequel, The Strawmen Murders, was published by Afrikaanse Pers Boekhandel (APB) in 1946. In an indication that this was still an unusual publishing genre locally, the latter was sub-titled "A South African detective story"; the cover art is recognisable for the genre, with a man in black carrying the body of a woman in red. The cover flaps also highlight the work's insertion in the crime genre, highlighting the words "murder", "a corpse", and "the killer", and asking, "Can you the reader beat [Inspector] Quayle to the solution?" APB's decision to publish in English as well as Afrikaans was probably related to the "book boom", and the awareness that there was a growing market and thus demand for locally produced titles in English. Some of Herman Charles Bosman's work, also originally published by APB, can also be considered as falling within the crime genre, notably Willemsdorp (written before 1951, but published only posthumously in 1977). This work uses the structure of a murder mystery to interrogate a range of issues. Peck refers to Willemsdorp as "the first South African mystery novel to use the genre to attack apartheid" (1997: 57).

Donald Swanson, better known as a film producer and director, wrote a few works in the 1950s and 1960s. As mentioned, his collection of short stories, Highveld, Lowveld and Jungle, was published by Dassie Books in 1956, and featured a story titled 'Murder in the Game Reserve'. The Oxford Companion notes that, in this story (wrongly credited to the year 1950), "the question is whether crafty rangers or wild beasts are responsible for the corpses strewn across the veld" (Herbert, 1999). A later thriller, The Freedom Killers, appeared in 1961 in London rather than South Africa, probably because of its subject matter - the blurb describes it as "a tense story of racial and personal tensions in South Africa, raw, shocking, at times 
brutal and yet entirely probable". However, Swanson reverted to a Cape Town publisher, Simondium, for titles in the 1960s, such as the travel book Assignment Africa (1965) and the satirical Sunrise over Tanesia (1965).

Simondium is an interesting publisher, which did not specialise in crime fiction by any means, although it also published the radio personality Michael Drin's Signpost to Fear (1964). Drin's work was explicitly marketed as part of the crime genre, with the dust jacket stating: "As his publishers, we believe that Signpost to Fear will find its place among the best of modern, compulsive thrillers ...." Reviews for this novel also clearly situated it in the genre, with Alan Forrest of the Cape Times even comparing it to Agatha Christie (quoted on the dust jacket for Drin's second work, McKilty's Bride, a historical novel). Better known for publishing Athol Fugard's The Blood Knot in 1963 and for non-fiction, Simondium did not commission crime novels specifically, but accepted submissions by authors who were already well-known in other fields and thus easily publicised in an uncertain marketplace.

Other local publishers who occasionally published mass market fiction can also be found. For instance, in the 1950s Bob O'Keefe - a well-known non-fiction writer and historian - brought out his detective stories with the small Pretoria-based publisher Spearhead Publications and then with Dassie Books. The former title (Diamonds Can Be Dangerous) is set largely in Johannesburg, with a private investigator as well as a group of policemen, while the latter (Gold without Glitter) is described on its blurb as "a fast moving South African mystery about the missing Kruger Millions in gold bullion". Both use the concept of illicit diamond buying, or IDB, as a central plot device. O'Keefe's first title was also translated into Afrikaans, as Die Vonkelende Dood, showing general local audience interest. Similarly, Peter Godfrey published his short stories, collectively known as Death Under the Table, with the South African Scientific Publishing Co. in Cape Town in 1954. These short stories feature an investigative team, of Inspector Dirk Joubert and Rolf le Roux, of the Cape Town CID. A follow-up title, also featuring Rolf le Roux, came out in 2002.

Apart from locally published books, in the 1940s and 1950s more ephemeral forms of crime fiction also emerged. One of these was the African Film magazine, with short stories featuring Lance Spearman as a crime fighter. The 1940s also saw the first black South African detective, in a series of short stories featured in Drum magazine. Writing as Arthur Mogale, Arthur Maimane introduced Detective Chester O. Morena, a "US-style" private detective. Gaylard notes that "the stories of Arthur Maimane ... are obviously indebted to writers such as Raymond Chandler and Peter Cheyney" but disagrees with Bernth Lindfors that "the private detective in Maimane's stories is patterned so closely on the American stereotype that "nothing about him or his adventures can be identified as authentically South African"” (Gaylard, 2008: $71,189)$. Maimane later began to produce protest writing under his own name, which has led to an 'over-simple dichotomy ... between 'the extravagant sensationalism' in Drum and the "angry protest in liberal publications"” (Gaylard, 2008: 189). The question of this dichotomy will be addressed later.

In spite of clear evidence of a rise in the readership of crime fiction, the 1960s and 1970s saw just a handful of titles published locally in English, although much more was produced in Afrikaans. This may be because of the increasingly repressive context during the apartheid period, but there may also be other, more commercial motives at play - in other words, the size of the local market was still generally considered too small for local English trade publishing to compete with imports. An exception is journalist David Brechin's two novels Nic Barber IDB (1963) and Uncut Diamonds (1969), both published by Nasionale Boekhandel. While Brechin was Scottish-born, he lived and worked in Kimberley, and in fact also published several novels in Afrikaans. The covers of the novels feature shadowy detectives, playing on generic tropes.

It was only in the 1970s and 1980s that general trade publishing really took off in South Africa, as well as other forms such as oppositional publishing. This period coincided with the 
rise of more general booksellers, such as Exclusive Books and the book club Leserskring. Previously, the only major outlet for trade bookselling was the CNA chain and a few independent bookshops. With the availability of more outlets for trade fiction, the local market also began to grow and develop.

In a reflection of the growing range of titles that this enabled, the young adult market became a significant platform for emerging authors in the crime genre. An example is Nandi Dlovu in the Macmillan Pacesetters series, featuring Soweto-born detective Zak Biko (1982). At almost exactly the same time, educational publisher Shuter \& Shooter published George Sabelo's first novel, featuring Skip Dlamini, again erroneously credited as "South Africa's first Black detective" according to the blurb (1983, co-published with the well-known trade and crime fiction publisher, Collins). The covers of these two works are strikingly similar, with images of strong, suited black men prominently carrying weapons.

\section{Publishing abroad}

With the small market and unwillingness of local publishers to take a chance on crime fiction, several of South Africa's best known crime writers chose to publish in London. In the 1960s, we find authors like Margaret Penrose (the pseudonym of Margaret Errington) and Peter Harris publishing several crime novels with John Long, a publisher of popular genre fiction. The jacket copy for Harris's first novel, Letters of Discredit, situates the genre, author and setting: "With this well-plotted crime novel - in which racy dialogue, believable characters and a calmly-observed Cape Town setting are combined - Peter Harris starts his career as a mystery writer". Others who were widely read and published overseas include suspense writers Geoffrey Jenkins and Alan Scholefield.

Arguably, South Africa's best-known crime fiction writers were all published abroad. For instance, Nicol (n.d.) locates June Drummond's The Black Unicorn (1959) as the first local crime novel in English, and she is often referred to as South Africa's "Queen of Crime". While Drummond lived in Durban for most of her life, her more than thirty titles were all published in London, first with Gollancz and later with Robert Hale. This decision to publish with established UK publishing houses is perhaps responsible for her international reputation today. Drummond's work was often, but not always, set in South Africa, yet it was usually packaged as mainstream English fiction, without calling attention to her 'exotic' milieu. Critics have commented that, "Her work is notable for its domestic detail, which in the hands of most overseas writers is merely exotic" (Herbert, 1999). This implies a marketing strategy of co-option into the mainstream, rather than commodification as a colonial exotic.

The second of these writers has been called "without doubt the founder of crime fiction in South Africa and its most internationally respected exponent" (Nicol, n.d.): James McClure, who lived and published in the UK from the 1970s. McClure's first novel, The Steam Pig, was published by Gollancz in 1971 and won the Gold Dagger award. The publisher chose to emphasise the author's alterity: the cover of the first edition is, in true Gollancz style, plain text on a yellow background, and highlights the author's "unique position" and authority to describe "verismo police procedure" in apartheid South Africa. (Later editions feature more generic cover artwork.) Reviews at the time also commented on the "exotic locale". McClure is widely featured in international collections of criticism on crime fiction for his Kramer and Zondi series, yet his books are almost unobtainable in South Africa. Peck notes, "The mystery is why James McClure's detective novels set in 'Trekkersburg' (Pietermaritzburg) are not better received in South Africa", asking, "Why is it that James McClure, who is arguably the best South African mystery writer, is virtually unknown in South Africa itself?" (Peck, 1995: 48, 49). 
The third key author is Wessel Ebersohn, whose first work, A Lonely Place to Die: A Novel of Suspense, was published in 1979, also by Gollancz. Ebersohn's second work, The Centurion, was published by Ravan Press in Johannesburg in 1980; he refers to the latter as "a little thriller" (2011), and it was clearly packaged as such in terms of the paratext of cover image and blurb: "an ominous new thriller by the bestselling author of $A$ Lonely Place to Die". The reception of Ebersohn's work also placed it within the crime genre - with, for instance, the Manchester Evening News calling his first book "a taut and gripping thriller" (quoted on blurb). He has since divided his work between thrillers and "straight" novels.

It is significant, perhaps, that these three authors were all initially published by Gollancz, a socialist and left-wing publisher that supported the anti-apartheid cause. Gollancz also became known for its crime fiction list, with authors such as Dorothy Sayers. Gollancz titles were regularly submitted to the censorship authorities, including works by Drummond, McClure and Ebersohn. Some were banned, while others were passed, but local booksellers may have been unwilling to take a chance on stocking too many potentially undesirable books from this publisher.

\section{Protest vs popularity}

While crime fiction is usually described, and perhaps dismissed, as mass-market fiction, there are times when it has a wider social import as well. A number of works have explored what Symons calls the "borderland between the crime story and the novel", creating a "socially conscious" strand of crime fiction (1972). This is not only an imperative for writers, but for publishers too: Ad Donker notes that, "It is a challenge for a publisher to balance his list between the commercially successful books, required for survival, while not neglecting the responsibility he has towards society" (1983: 34). In South Africa, various anti-apartheid activist authors were generally categorised under 'protest literature' - although in truth their work fell into a wide range of genres. Those whose work could be considered crime fiction include Peter Abrahams, Lewis Nkosi, Alex La Guma and Andre P. Brink, the latter whose A Dry White Season "might perhaps be said to have flirted with the genre" (Davis, 2006: 182).

McClure, deliberately, traces his inspiration to write crime fiction to the "neutrality of the crime story" and the potential to reach a wide audience:

Every novel about South Africa that I'd come across until then had been self-limiting I felt, in that its anti-apartheid slant had made it appeal only to the 'converted'... Crime or mystery novels, on the other hand, appealed to pretty well everyone, including the more conservative, if not downright reactionary, reader. This meant I could simply write 'the way it was' and leave people to make their own moral judgments while the point of the tale remained 'who done it?' (quoted in Green, 1997)

However, international reception of McClure's work focuses on his critique of apartheid: "McClure has chosen the vehicle of the mystery novel, more exactly the 'police procedural', to examine the effects of prejudice upon his native land" (Lockwood, 1983: 440). This implies the use of crime fiction as a vehicle for social protest, precisely because "the mystery novel reaches a wider and largely different audience than 'political' novels such as those of Alan Paton, Nadine Gordimer, and Andre Brink" (Lockwood, 1983: 441). The Sunday Hangman was banned in South Africa, because it discussed capital punishment and prison conditions, while "the paperback edition of one of [McClure's] books was banned because the publisher foolishly included on the cover words to the effect that it was a stinging indictment of the apartheid system" (Lockwood, 1983: 441). In other words, the publicity campaign, while attempting to play up the social commentary aspect of an otherwise genre-bound novel, had an unintended impact on local sales. 
Given that most of the international academic criticism of these works focuses on what they reveal of South Africa under the apartheid system (e.g. Davis, 2006), it could be seen as a subversive strategy on the part of both authors and publishers to critique the system using the medium of a supposedly mass-market, apolitical genre. Peck (1995: 49) describes several authors who "broke from the usual conservatism of their genre and from the tradition of pro-apartheid tales". Ebersohn, like McClure, is considered "remarkable not only for the skill with which detective fiction is woven into a complex account of apartheid society, but also for the perceptive psychological and sociological analysis to which that social order is subjected" (Davis, 2006: 195).

Ravan Press, David Philip and Ad Donker, some of the best-known oppositional publishers, all produced works of crime fiction, while Gollancz in London was also associated with progressive and anti-apartheid publishing. Thus, even though commentators like Green (1997: 209) suggest that the detective story was not "a viable form of oppositional writing", there is scope for a re-consideration of this genre in the place of South African publishing history. For the future, Warnes (2012: 991) argues that "[i]n the context of post-apartheid South Africa, the particular resources that this genre offers make it possible for writers to exercise both readerly and socially responsible reflexes: to write in a way that feels appropriately 'new,' attracting a wide and diverse range of readers, while maintaining some of the commitment to political and social conscientising that has long been a feature of South African literatures."

\section{Conclusion}

It appears to have been common practice shortly after World War II for South African authors to publish either with well-known London publishers or with smaller local publishers; it was only later that South African publishing houses became more established and that a few came to dominate the trade market. It is widely accepted in the publishing industry that "independent production companies more often discover new talent than the big conglomerates because it is easier for them to take risks" (Williams, 2007). The somewhat sporadic and seemingly ad hoc publishing of a few titles in this genre by a variety of publishers supports the view that South African publishing houses were trying out a variety of genres at the time, rather than specialising in specific areas.

The "explosion" of crime writing since the 1990s - and often dated explicitly to the publication of Deon Meyer's first novel, Wie Met Vuur Speel (1994) - can thus be seen as the result of several factors. More local publishers are willing to produce local novels, there is greater demand for new, local voices coupled with greater willingness to buy South African books, there have been improvements in marketing and packaging, and the number of bookshops catering for trade fiction has grown. Since then, the numbers of new titles have certainly grown, and a few publishers in particular are actively building their lists in this genre: Kwela and Human \& Rousseau above all, but also Umuzi, Jacana, LAPA and Penguin.

This explosion may also be related to the boom in crime writing worldwide, in terms of both numbers and range of titles. There has been a related boom in other media associated with crime storylines, including television series, films, computer games, and magazines. So, while individual titles may still be seen as low-brow or ephemeral, the genre itself is seen as having relevance and viability. The current publishing environment is extremely competitive, with print runs growing, the range of titles widening, promotional efforts becoming stronger (especially in the area of publicity due to social media and the internet), and readership demographics broadening. Crime fiction is now classified as "general commercial fiction" (Williams, 2007), and is "one of the most visible and popular kinds of literature today" (Bell and Daldry, 1990: ix). In South Africa, the broad "Crime/Mystery" category is second in popularity in terms of fiction, behind 
the catch-all "General \& Literary Fiction" (Betts, 2012), based on sales figures, while 24\% of readers report regularly reading "crime/thrillers" (SABDC, 2007: 69). There is thus a great deal of optimism for the future of publishing in this genre.

\section{References}

African Crime Fiction Project. Online:http://www.libraries.iub.edu/index.php?pageld=1002699.

Asong, Linus. 2012. Detective Fiction and the African Scene. Mankon: Langaa Research \& Publishing.

Bell, Ian and Graham Daldry (eds). 1990. Watching the Detectives: Essays on Crime Fiction. Basingstoke: Macmillan.

Betts, Ann. 2012. "Global Book Sales Insights." Presentation to PASA/SABA conference, Johannesburg.

Davis, Geoffrey V. 2006. "Political Loyalties and the Intricacies of the Criminal Mind: The Detective Fiction of Wessel Ebersohn." In Matzke, Christine and Susanne Mühleisen (eds). Postcolonial Postmortems. Amsterdam: Rodopi.

Dove, George. 1997. The Reader and the Detective Story. Ohio: Bowling Green State University Press.

Ebersohn, Wessel. 2011. 'Q and A with Wessel Ebersohn'. Online: http://www.wesselebersohn.com/q-and-awith-wessel-ebersohn/.

Ensor, Jason. 2008. "Reprints, International Markets and Local Literary Taste: New Empiricism and Australian Literature." JASAL, Special issue: 198-218.

Evans, Nicholas and Monica Seeber (eds). 2000. The Politics of Publishing in South Africa. Scottsville: University of Natal Press.

Ford, Jane. 2009. "Spectral Economies at the Anglo-African Margin: Bertram Mitford's Predatory Politics of Consumption." Victorian Network, 1(1): 6-21.

Friedland, Susan. 1972. South African Detective Stories in English and Afrikaans from 1951-1971: A Bibliography. Johannesburg: Witwatersrand University Press.

Gaylard, Rob. 2008. "Writing Black: The South African Short Story by Black Writers." DLitt thesis, University of Stellenbosch.

Genette, Gerard. 1997. Paratexts: Thresholds of Interpretation. Cambridge: Cambridge University Press.

Green, Michael. 1997. Novel Histories. Johannesburg: Witwatersrand University Press.

Herbert, Rosemary (ed.). 1999. The Oxford Companion to Crime and Mystery Writing. Oxford: Oxford University Press.

Hofmeyr, Isabel. 1978. "The Mining Novel in South African Literature: 1870-1920.” English in Africa, 5(2): $1-16$.

Hooper, A.S.C. 1997. "History of the South African Publishing and Book Trade." In P.E. Westra and L.T. Jones (eds). The Love of Books: Proceedings of the Seventh South African Conference of Bibliophiles. Cape Town: South African Library.

Hubin, Allan J. 2008. Crime Fiction IV: A Comprehensive Bibliography 1749-2000. Oakland: Locus Press. Online: http://www.crimefictioniv.com/

Huggan, Graham. 1994. "The Postcolonial Exotic.” Transition, 64: 22-9.

Killam, Gordon D. and Alicia L., Kerfoot. 2008. Student Encyclopedia of African Literature. Westport: Greenwood Press.

Lieven, Michael. 1998. "Contested Empire: Bertram Mitford and the Imperial Adventure Story." Paradigm, 25. Online: http://faculty.education.illinois.edu/westbury/paradigm/lieven2.html.

Lockwood, Bert, Jr., 1983. "A Study in Black and White: The South Africa of James McClure." Human Rights Quarterly, 5: 440-66.

Matzke, Christine and Susanne Mühleisen. 2006. "Postcolonial Postmortems: Issues and Perspectives." In Matzke, Christine and Susanne Mühleisen (eds). Postcolonial Postmortems. Amsterdam: Rodopi.

Miller, Anita. 1967. Afrikaanse Speurverhale Uitgegee tot die Einde van 1950. Johannesburg: Wits University Press.

Monsman, Gerald. 2011. "The Early Empire Fiction of Ernest Glanville.” English Literature in Transition, 54(3): 315-36.

Morse, Ruth. 2005. "Racination and Ratiocination: Post-Colonial Crime." European Review, 13(1): 79-89.

Nicol, Mike. n.d. Online: http://crimebeat.bookslive.co.za/whos-who-of-south-african-crime-writing/

Nicol, Mike. n.d. Online: http://crimebeat.bookslive.co.za/a-short-history-of-south-african-crime-fiction/

Peck, Richard. 1995. "The Mystery of McClure's Trekkersburg Mysteries: Text and Non-Reception in South Africa." English in Africa, 22(1): 48-71.

Peck, Richard. 1997. A Morbid Fascination. Westport: Greenwood Press. 
Rosenthal, Eric. 1970. "Trends in South African Publishing." English Studies in Africa, 13(1): 275-90.

Schleh, Eugene (ed.). 1991. Mysteries of Africa. Ohio: Bowling Green University Press.

South African Book Development Council (SABDC). 2007. National Survey into the Reading and Book Reading Behaviour of Adult South Africans. Cape Town: SABDC.

Spehner, N. 2012. Crime Scene: Africa, A Bibliography. Online: http://en.calameo.com/read/ $000259481772021 \mathrm{e} 750 \mathrm{c} 2$.

Symons, Julian. 1972. Bloody Murder: From the Detective Story to the Crime Novel. London: Faber.

Tian, Xuemei. 2008. "Book Publishing in Australia: The potential impact of digital technologies on business models." DPhil thesis, RMIT University, Australia.

Van Wyk Smith, Malvern. 1990. Grounds of Contest: A Survey of South African English Literature. Cape Town: Juta Press.

Warnes, Christopher. 2012. "Writing Crime in the New South Africa." Journal of Southern African Studies, 38(4): 981-91.

Wikipedia. 2012. “Angela Makholwa.” Online: http://en.wikipedia.org/wiki/Angela_Makholwa.

Williams, Wilda. 2007. "The Killer Genre: New Talent and Publishing Initiatives Build Suspense for Mystery Readers." Library Journal, 132(7): 38-41. 
South African crime and detective fiction in English: An initial bibliography up to 1994

\begin{tabular}{|c|c|c|c|c|c|}
\hline Author & Title & Place of Publication & Publisher & $\begin{array}{l}\text { Year of } \\
\text { first pub. }\end{array}$ & Notes \\
\hline Abrahams, Peter & 1965 A Night of Their Own & New York & Knopf in US; Faber in UK & 1965 & Protest writer. \\
\hline Bennett, Benjamin & 1951 Murder is my Business & Cape Town / London & $\begin{array}{l}\text { Howard B. Timmins / } \\
\text { Hodder \& Stoughton }\end{array}$ & 1951 & True crime. \\
\hline Bernstein, Hilda & 1983 Death is Part of the Process & London & Sinclair Browne & 1983 & $\begin{array}{l}\text { UK-born activist \& non- } \\
\text { fiction author; set in SA. }\end{array}$ \\
\hline $\begin{array}{l}\text { Bosman, Herman } \\
\text { Charles }\end{array}$ & 1977 Willemsdorp & Johannesburg & APB & 1977 & \\
\hline Brechin, David & $\begin{array}{l}\text { 1963Nic Barber IDB } 1969 \text { Uncut diamonds } \\
1982 \text { Rock Shock: Clifton Beach, diamonds } \\
\text { and murder }\end{array}$ & Cape Town & $\begin{array}{l}\text { Nasionale Boekhandel } \\
1982 \text { Self-pub }\end{array}$ & 1963 & $\begin{array}{l}\text { UK-born journalist; worked } \\
\text { in SA. }\end{array}$ \\
\hline Brink, Andre & $\begin{array}{l}1979 \text { A Dry White Season } 1992 \text { An Act of } \\
\text { Terror } 1996 \text { Imaginings of Sands Etc. }\end{array}$ & New York & $\begin{array}{l}\text { Simon \& Schuster; } \\
\text { Harcourt Brace }\end{array}$ & 1979 & $\begin{array}{l}\text { Protest writer. Literary fiction } \\
\text { with crime elements. }\end{array}$ \\
\hline Burmeister, Jon & $\begin{array}{l}1968 \text { The Edge of the Sky } 1972 \text { Running } \\
\text { Scared } 1973 \text { The Edge of the Coast } 1989 \\
\text { The Plekhanov Original }\end{array}$ & London & $\begin{array}{l}\text { Severn House / Michael } \\
\text { Joseph }\end{array}$ & 1968 & \\
\hline Butler, K.R. & 1964 A Desert of Salt 1967 A Fall of Rock & London & Geoffrey Bles & 1964 & $\begin{array}{l}\text { UK-born journalist; worked } \\
\text { in SA. }\end{array}$ \\
\hline $\begin{array}{l}\text { Campbell, } \\
\text { Alexander }\end{array}$ & $\begin{array}{l}1945 \text { Fell Purpose } 1946 \text { The Strawmen } \\
\text { Murders: A South African detective Story }\end{array}$ & $\begin{array}{l}\text { Cape Town / London } \\
\text { Johannesburg }\end{array}$ & $\begin{array}{r}\text { Howard Timmins / Hodder } \\
\text { \& Stoughton; } 1946 \text { APB }\end{array}$ & 1945 & \\
\hline Clarke, Anna & 1968 The Darkened Room Etc. & London & Chatto \& Windus & 1968 & $\begin{array}{l}\text { SA-born author, later moved } \\
\text { to UK. Popular series still } \\
\text { in print. }\end{array}$ \\
\hline Clarke, Phillip & 1990 Adventures at Dabanga School & Cape Town & OUP & 1990 & \\
\hline Croudace, Glynn & $\begin{array}{l}1956 \text { Transvaal Jade \& other stories } 1957 \\
\text { Motives for Murder } 1968 \text { The Silver Grass } \\
1969 \text { Blackadder } 1969 \text { The Scarlet Bikini } \\
1988 \text { The Secret of the Rock }\end{array}$ & $\begin{array}{l}\text { Johannesburg } \\
\text { London Cape } \\
\text { Town }\end{array}$ & $\begin{array}{l}\text { Dassie Books (CNA) } \\
\text { Robert Hale; } \\
\text { Macmillan; } 1988 \\
\text { Maskew Miller } \\
\text { Longman }\end{array}$ & 1956 & \\
\hline De Waal, Johann & 1990 Machado & Johannesburg & Penguin SA & 1990 & $\begin{array}{l}\text { Published simultaneously in } \\
\text { Afrikaans by HAUM }\end{array}$ \\
\hline Dlovu, Nandi & $\begin{array}{l}1982 \text { Angle of Death } 1983 \text { Race Against Rats } \\
1995 \text { Murder by Magic }\end{array}$ & London & Macmillan Pacesetters & 1982 & $\begin{array}{l}\text { First name sometimes listed } \\
\text { as Annoi. Also YA } \\
\text { romance fiction. }\end{array}$ \\
\hline
\end{tabular}


Dreyer, Peter

Drin, Michael

Driscoll, Peter

Drummond, June

Du Camp, Alwyn

Ebersohn, Wessel

Galgut, Damon

Gardiner, Gordon

Glanville, Ernest

Godfrey, Peter

Graham, Mark

Gray, Stephen

Greene, L. Patrick

Grosskopf, Hein Harris, Peter
1969 A Beast in View

1964 Signpost to fear

1972 The Wilby Conspiracy 1976 The Barboza Credentials 1988 Spearhead Etc.

1959 The Black Unicorn 1959 Northern

Miner 1961 Thursday's Child not crim

1962 A Time to Speak not crim 1964

Welcome, Proud Lady Etc.

1969 Twana 1977 Cyclone Capricorn

1979 A Lonely Place to Die 1980 The Centurion 1981 Divide the Night 1990 Closed Circle 2009 The October Killings 2010 Those who Love Night 2012 The Top Prisoner of C-Max Etc.

1982 A Sinless Season 1995 The Quarry 2008 The Imposter Etc.

1914 The Reconaissance 1928 At the House of Dree 1929 The Pattern of Chance 1932 The Man with a Weak Heart

1894 A Fair Colonist 1891 The Lost Heiress Etc.

1954 Death under the table 2002 The Newtonian Egg, and other cases of Rolf le Roux

1988 The Harbinger

1994 Drakenstein: A novel

1924 The Major-Diamond Buyer 1928 The

Devil's Kloof 1928 The Red Idol 1928

Major Adventures 1929 Dynamite Drury Etc.

1993 Artistic Graves: A political thriller

1964 Letters of Discredit 1965 The Final Set 1970 Cry Hold!
London

Cape Town

New York

London

Clairwood

London

Johannesburg

Cape Town

Johannesburg /

New York

New York / London

London

Cape Town Norfolk, VA

London

Johannesburg

New York

Johannesburg

London
Andre Deutsch

Simondium

Lippincott; 1988 Bantam

Victor Gollancz; From 2003 Robert Hale

Mercantile Printing Works (self-pub?); 1977

Stockwell

Gollancz; 1980 Ravan;

From 2009 Umuzi

Jonathan Ball / Penguin Books

Macmillan / Sampson

Low, Marston

Chatto \& Windus

SA Scientific Publishing Co Crippen \& Landrau

Headline

Justified Press

Doubleday, Page \& Co

1988

1994

1924

Ravan; Press

John Long

1969

1964

1972

1969
Canadian-born radio personality, lived in SA.

UK-born writer, lived in SA.

"SA's Queen of Crime"

Not only crime fiction.

Not only crime fiction.

UK-born author, worked in SA.

SA writer; adventure genre.

88

UK-born author, lived in Southern Africa and US.

First name spelt Louis or Lewis. 
Jacobs, Steve

Jenkins, Geoffrey

Jute, Andre

La Guma, Alex

Levitt, Wilfred

Lindsay, Kathleen aka Desmond, Hugh

Luman, Reginald E.

Maimane, Arthur (writing as

Arthur Mogale) McClure, James

Mitford, Bertram

Niesewand, Peter

Nkosi, Lewis
1984 Light in a stark age 1986 Diary of an Exile 1993 Under the Lion 1995 The Enemy Within

1959 A Twist of Sand 1960 The WateringPlace of Good Peace 1962 A Grue of Ice 1964 The River of Diamonds 1966 HunterKiller 1971 Scend of the Sea Etc.

1979 Reverse Negative: A novel of suspense 1979 Time of the Butcherbird Etc.

1982 Narrative Murder 1990 Time for Murder

1939: The Slasher Etc. +78 others in crime genre

1977 Blind Justice: A thriller

1953 short story series with Detective Chester O. Morena aka The Chief 1976 Victims aka Hate no More (2000 re-edition by Kwela) 1971 The Steam Pig 1972 The Caterpillar Cop 1974 The Gooseberry Fool 1975 Snake 1977 The Sunday Hangman 1980 The Blood of an Englishman 1984 The Artful Egg 1988 Imago 1992 The Song Dog

1894 Renshaw Fanning's Quest 1897 The Sign of the Spider 1899 The Weird of Deadly Hollow Etc.

1979 A Member of the Club 1979 The underground connection 1983 Scimitar 1986 Mating Birds 2003 Underground People
Johannesburg

London

London

Melbourne

London

Cape Town

Johannesburg

Pietermaritzburg

London

Cape Town

Johannesburg

London

London

London

London

Nairobi; Cape Town
Ravan; Ad Donker

Heinemann AWS

Collins; later

HarperCollins

Hyland

Heinemann

Jane Cowen?; Justified

Press

Albatross / Various

Self-pub

Drum Busby

Gollancz

Chatto \& Windus; Methuen FV White

1890s

Secker \& Warburg / Pan

1979

East African Pub. House 2003 Kwela

1984

1979

1979

1982

1930 s

on

1977

946

1986
SA author, lived abroad.

Protest writer. Many pseudonyms, many genres.

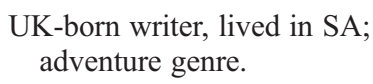

UK-born writer, lived in SA; adventure genre.

Protest writer.
UK-born writer,lived in SA. 
O'Keefe, Bob

1953 Diamonds can be Dangerous 1957

Gold without Glitter 1957 Game without reserve

One Who Was In It Kruger's Secret Service

(Douglas

Blackburn)

Packer, Joy

Penrose, Margaret

(Margaret

Errington)

Peter, John

Phillips, Mary

Sabelo, George

Scholefield, Alan

(Lee Jordan)

Sherlock,

Christopher

Slovo, Gillian

Stander, Siegfried

1971 The Dark Curtain Etc.

1961 Death on the Files 1963 The Fatal Fifth London

1969 Runaway 1964 Along that coast

1994 The Day of the Dragon: A Simon Dube Adventure 1994 Wake not the Wolf: A

Simon Dube adventure Etc.

1983 Scar of the Tigers: A Skip Dlamini Thriller 1983 Target: The President

1966 A View of Vultures 1983 The Sea Cave 1990 Dirty Weekend series 1991 Thief

Taker Etc.

1990 Hyena Dawn 1991 Night of the Predator Etc.

1984 Morbid Symptoms: A murder mystery 1986 Death by analysis 1987 Death comes staccato 1991 The Betrayal Etc.

1972 The Fortress 1977 Flight from the Hunter 1979 Leopard in the Sun 1983 Into the Winter

Starke, Roland

1967 Freedom Ceremony

Swanson, Donald

1956 / 57 Highveld, Lowveld and Jungle (short stories) 1961 The Freedom Killers 1965 Assignment Africa 1965 Sunrise over Tanesia

Uys, Ian

1987 The Comrades Etc.
London

Pretoria Jhb

London

New York

Johannesburg

Pietermaritzburg

London

London

London

New York; London

Boston; London

London

Johannesburg

London; Cape

Town

Germiston
Spearhead Publications 1957 Dassie Books

$$
\text { (CNA) }
$$

John Macqueen

Methuen

John Long

Doubleday

Justified Press

Shuter \& Shooter / co-pub 1983 Collins

Heinemann Macmillan

1966

Heinemann

1990

Dembner Books; Michael Joseph; WW Norton

Houghton Mifflin; Arrow Books

1972

Macdonald's, Triton

Books

Dassie Books (CNA);

Peter Davies;

Simondium

Uys Publishers (self-pub)
Historical romances, but also crime elements.

Not all crime genre

SA-born writer, lives in UK

UK-born author emigrated to SA.

Also Afrikaans 
Van Rensburg, $\quad 1954$ Death in a Dark Pool 1955 The man Helen \&

Louwrens

Van Staden, Jef

Van Zyl, PR

Venter, Al J.

Webster, Elizabeth

Charlotte

Westrup, William

Wiles, Frank J. with two ties 1958 The siege of Aunt Estelle

1992 Showdown 1993 Lone fighter

1974 The Prosecutor

1980 Soldier of Fortune

1927 Pot Holes; An Adventure of the

Diamond Fields

1929 Shadows in the Water Etc.

London

Johannesburg

New York

London

Johannesburg /

London

London

London
Michael Joseph;

Macmillan

$\begin{array}{ll}\text { Vivlia } & 1992 \\ \text { Berkeley / Putnam } & 1974 \\ \text { WH Allen } & 1980 \\ \text { Dassie Books (CNA) / } & 1927 \\ \quad \text { Chapman \& Hall } & \end{array}$

John Lang

Research Publishing

Company
927

1929

UK-born writer lived in SA. Other titles from 1911, not crime genre. 